\title{
Behaviour of Steel Plate Shear Wall in Multi Span Moment Frame with Various Infill Plate Connection to Column
}

\author{
Amirhosein Raisszadeh ${ }^{\text {a }}$, Alireza Rahai ${ }^{a}$, Ardeshir Deylami ${ }^{{ }^{*}}$ \\ ${ }^{a}$ Dept. of civil \& environmental engineering, Amirkabir University of Technology, Tehran, Iran .
}

Received 28 October 2017; Accepted 15 January 2018

\begin{abstract}
Steel plate shear walls consist of thin infill steel plates attached to beams, called (horizontal boundary elements, HBEs), and columns (vertical boundary elements, VBEs) in structural steel frames. The thin unstiffened web plates are expected to buckle in shear at low load levels and develop tension field action, providing ductility and energy dissipation through tension yielding of the web plate. HBEs are designed for stiffness and strength requirements and are expected to anchor the tension field formation in the web plates. VBEs are designed for yielding of web plates and plastic hinge formation at the ends of the HBEs. This design approach may result in very large demand on boundary frame members, especially VBEs in most cases. Several methods such as using LYP, perforating the infill plate and omitting connection of infill plate to columns have been proposed to reduce the moment and axial force demands on the VBEs. The main purpose of this research is to study the behavior of steel plate shear walls with various connection of infill plate to columns in multi span moment frames. A numerical study has been performed in order to investigate the behavior of such a system. The results of proposed system were compared with those of the conventional SPSWs. Results show that reducing the infill plate connection to columns will reduce the axial forces in columns.
\end{abstract}

Keywords: SPSW; Multi Span Moment Frame; Ultimate Capacity; Axial Force.

\section{Introduction}

Steel plate shear walls (SPSW) are efficient lateral load resisting systems and can be used as an efficient alternative to traditional systems. Depending on their slenderness, SPSW may yield under applied shear before they buckle or may buckle while almost elastic. Depending on the construction and design, the plate walls may be stiffened or unstiffened. Prior to the 1980s, SPSW design was based on the concept of preventing the out of plane buckling of the infill panel by the use of heavily stiffened steel plates [1]. SPSWs presented good seismic behaviour due to their energy dissipation capacity through the shear mechanism in infill plates. However, when compared with reinforced concrete shear walls, the system was not very competitive, because of its higher cost. In order to make the SPSW more competitive, further studies focused more on slender systems, which utilize unstiffened thin walled steel panels and resist lateral forces mainly through post-buckling tension field action [2-6].

The main advantages of slender SPSW consist of economy in steel weight due to thinner walls, fast construction time and easier retrofit [7]. Furthermore, with acceptable design and detailing, SPSW systems may be classified as ductile systems. Code designed SPSWs are also capable of meeting drift limitations when subjected to ground motions [8]. However, there are some concerns regarding the seismic response of slender steel plate shear wall systems because they buckle during the early stages of lateral loading and therefore the response of the system is characterized by pinched cyclic behaviour. The pinching effect decreases the area of the hysteresis loops and, as a result, decreases the energy absorption of SPSW. In order to reduce pinching and increase energy absorption, plate walls may be combined

* Corresponding author: deylamia@aut.ac.ir

doi) http://dx.doi.org/10.28991/cej-030974

> This is an open access article under the CC-BY license (https://creativecommons.org/licenses/by/4.0/).

(C) Authors retain all copyrights. 
with rigid moment frames as boundary elements. The resulting frame action provides some stiffness around zero storey drift [6].

Many previous experimental and analytical studies have shown that the column demands in a SPSW are extremely large. Column flexural demands result from the development of the tension field in the infill plate (pull-in) and from the frame action of the boundary moment frame. Column axial demands result primarily from resisting the overturning moment and can be large for multi-story SPSWs, Column axial demands is also the result of infill plate pull in forces vertical component. These significant demands on SPSW columns can result in heavy columns. To reduce column demands in SPSWs, some researchers have investigated the use of low yield point steel for the infill plate, reduced beam sections at beam-to-column connections, and strategic placement of holes in the infill panels [9, 10].Some other researchers reduced the column forces using semi supported steel plate shear walls, which the infill plate is connected to secondary columns that are placed to anchor the plate forces. They also developed an evaluation for ultimate capacity of such a system $[11,12]$. Other researchers disconnected steel plate from columns to eliminate pull-in forces $[13,15]$. The contribution of the infill plate connected only to the beams of the boundary frame was found to be significant in terms of energy dissipation, initial stiffness and lateral strength. SPSWs with infill plates attached only to the beams should be useful for retrofitting and strengthening steel frames that have inadequate stiffness and strength with reduced labour and material savings due to the absence of the connections between columns and infill plate edges[14].Park[13] reported that SPSWs with infill plates connected only to the beams exhibited an excellent deformation capacity equivalent to that of the walls with fully connected infill plates, although its load-carrying capacity and energy dissipation capacity decreased. Some researchers investigated the effect of outrigger beams on the behaviour of steel plate shear walls [16-18]. The results show that stiffness load carrying capacity and energy absorption of the system increased considerably.

In this paper study of the behaviour of steel plate in multi span moment frame is done. Also various infill plate connection to columns and its effect on column axial forces is studied.

\section{Method of Study}

\subsection{Geometric Specifications of Models}

Twelve models in this study are considered. Each model consists of one-story three span moment frame which an infill plate is placed in the middle span as shown in Figure 1. Span width are assumed $3.5 \mathrm{~m}, 7 \mathrm{~m}$ and $8.75 \mathrm{~m}$. The story height is presumed to be $3.5 \mathrm{~m}$, so the aspect ratio of SPSWs varies from 1 to 2.5 . Beams are connected to columns through reduced beam section (RBS) moment connection. The column bases is completely restrained in 3 directions. Top of the beams also restrained perpendicular to the frame plane to consider floor effect. The load is applied through displacement at top of columns. In all models the infill plate is fully connected to beams but four different type of connection between infill plate and columns are assumed for each span width.

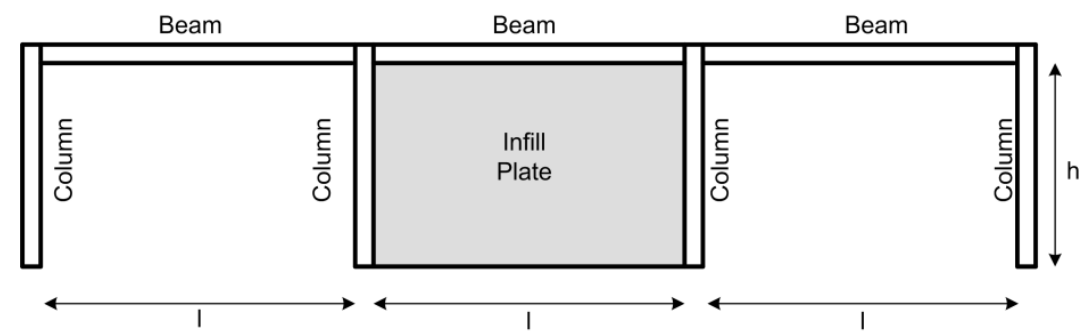

Figure 1. Schematic View of Proposed Models

In the first connection type, the infill plate is fully connected to columns, In the second and third connection types the infill plate is connected 20 and 50 percent of its length to columns respectively, as pictured in Figure 2, and finally in the fourth connection type there is no connection between the infill plate and the columns as pictured in Figure 3.

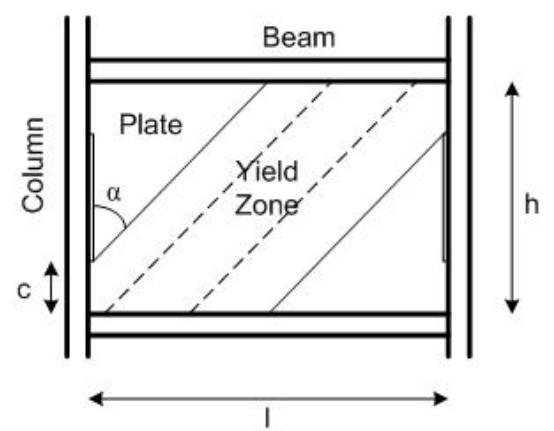

Figure 2. Partial Connection of Infill Plate to Column 


\subsection{Material Properties}

The ASTM-A36 and ASTM-A572 conventional structural steels are selected respectively for infill plate and frame members. Multilinear elastic-plastic behaviour for materials is assumed and the stress-strain diagrams for both materials (with $E=200 \mathrm{GPa}$ and $v=0.3$ ) are shown in Figure 4. Based on this figure, the yield strength of the infill plate $(250 \mathrm{MPa})$ is lower than that of frame members $(345 \mathrm{MPa})$ to let the infill plate yield before frame members and reduce the forces applied by infill plate on VBEs and HBEs.

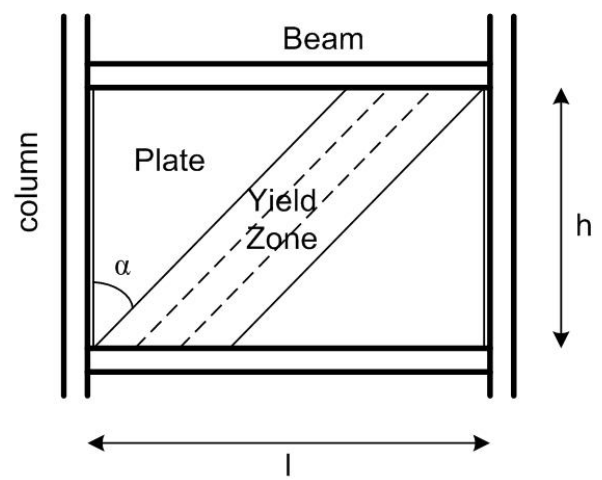

Figure 3. No Infill Plate Connection to Column

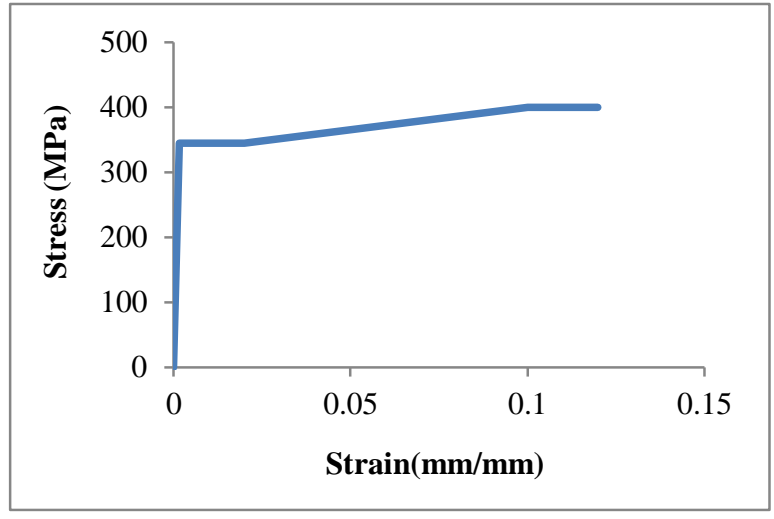

(a)

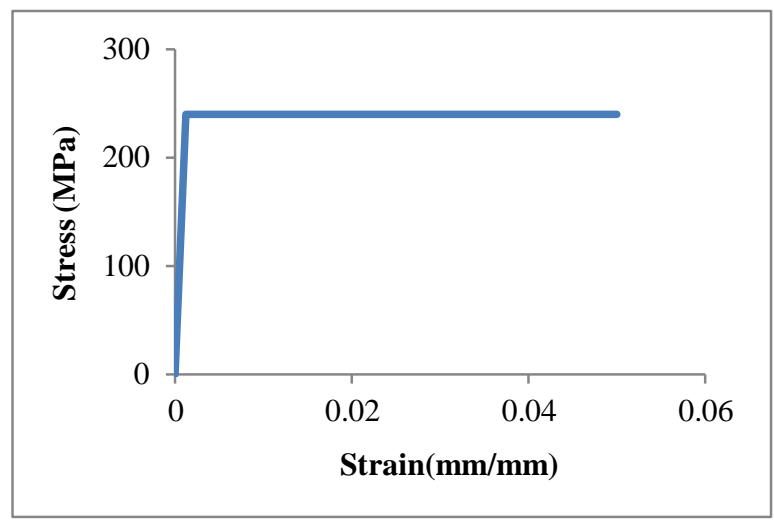

(b)

Figure 4. Material Properties: (a) Frame Members; (b) Infill Plate

\subsection{Design Procedure}

Frames were designed according to the AISC-341 [19] specifications. To study the effect of type of connection on VBEs demand, the models with same aspect ratio are designed to resist the same base shear. So the infill plate thickness for the model which infill plate is completely connected to column is assumed 5mm and the infill plate for other connection types is calculated. The frame specification for all types of connection in each aspect ratio is the same and are designed to resist forces induced by yielding infill plate according to the principles of capacity design method per AISC-341. The moment connection details are composed of reduced beam sections (RBS) to ensure the inelastic action at HBE ends away from the face of VBEs. The designed infill plate thickness and sections of frames are given in Tables 1 to 3 .

Table 1. Design sections - 3.5m span models

\begin{tabular}{ccccc}
\hline Model & Plate thickness $(\mathbf{m m})$ & Column & Beam & Connection detail of infill plate \\
\hline $3.5-100$ & 5 & $\mathrm{~W} 12 \times 136$ & $\mathrm{~W} 12 \times 106$ & Fully connected to column \\
$3.5-50$ & 5.7 & $\mathrm{~W} 12 \times 136$ & $\mathrm{~W} 12 \times 106$ & $50 \%$ connected to column \\
$3.5-20$ & 6 & $\mathrm{~W} 12 \times 136$ & $\mathrm{~W} 12 \times 106$ & $20 \%$ connected to column \\
$3.5-0$ & 13 & $\mathrm{~W} 12 \times 136$ & $\mathrm{~W} 12 \times 106$ & No connection to column \\
\hline
\end{tabular}


Table 2. Design sections - 7m span models

\begin{tabular}{|c|c|c|c|c|}
\hline Model & Plate thickness (mm) & Column & Beam & Connection detail of infill plate \\
\hline $7-100$ & 5 & W18x175 & W18x175 & Fully connected to column \\
\hline $7-50$ & 6.5 & W18x175 & W18x175 & $50 \%$ connected to column \\
\hline $7-20$ & 8 & W18x175 & W18x175 & $20 \%$ connected to column \\
\hline $7-0$ & 10 & W18x175 & W18x175 & No connection to column \\
\hline
\end{tabular}

Table 3. Design sections - 8.75m span models

\begin{tabular}{|c|c|c|c|c|}
\hline Model & Plate thickness (mm) & Column & Beam & Connection detail of infill plate \\
\hline $8.75-100$ & 5 & $\mathrm{~W} 24 \times 207$ & W24x207 & Fully connected to column \\
\hline $8.75-50$ & 6 & $\mathrm{~W} 24 \times 207$ & $\mathrm{~W} 24 \times 207$ & $50 \%$ connected to column \\
\hline $8.75-20$ & 7 & W24x207 & W24x207 & $20 \%$ connected to column \\
\hline $8.75-0$ & 8.5 & W24x207 & W24x207 & No connection to column \\
\hline
\end{tabular}

\subsection{FE Modeling}

The finite element analysis is carried out using ABAQUS program. The entire infill plate and boundary elements were meshed using the S4R shell elements, a four node doubly curved general-purpose conventional shell element with reduced integration and hourglass control. Reduced integration together with hourglass control can provide more accurate results, as long as the provided elements are not distorted (relatively close to being square in shape).Using this element significantly reduces running time especially in three dimensional models. Initial imperfections were applied in the models to help initiate panel buckling and development of tension field action.

To ensure the accuracy a convergence study was carried out to verify the numerical modeling. A simple square infill plate under pure shear was meshed into different number of elements and the buckling stress was compared to classic Equation 1.

$\tau_{c r}=\frac{k \pi^{2} E}{12\left(1-v^{2}\right)}\left(\frac{t_{w}}{h}\right)^{2}$

Figure 5 shows the percentage of error comparing finite element model result to theoretical value for different element mesh sizes. Based on this figure a mesh size of $150 \mathrm{~mm}$ has a good agreement with theory and taken as the minimum requirement for analysis.

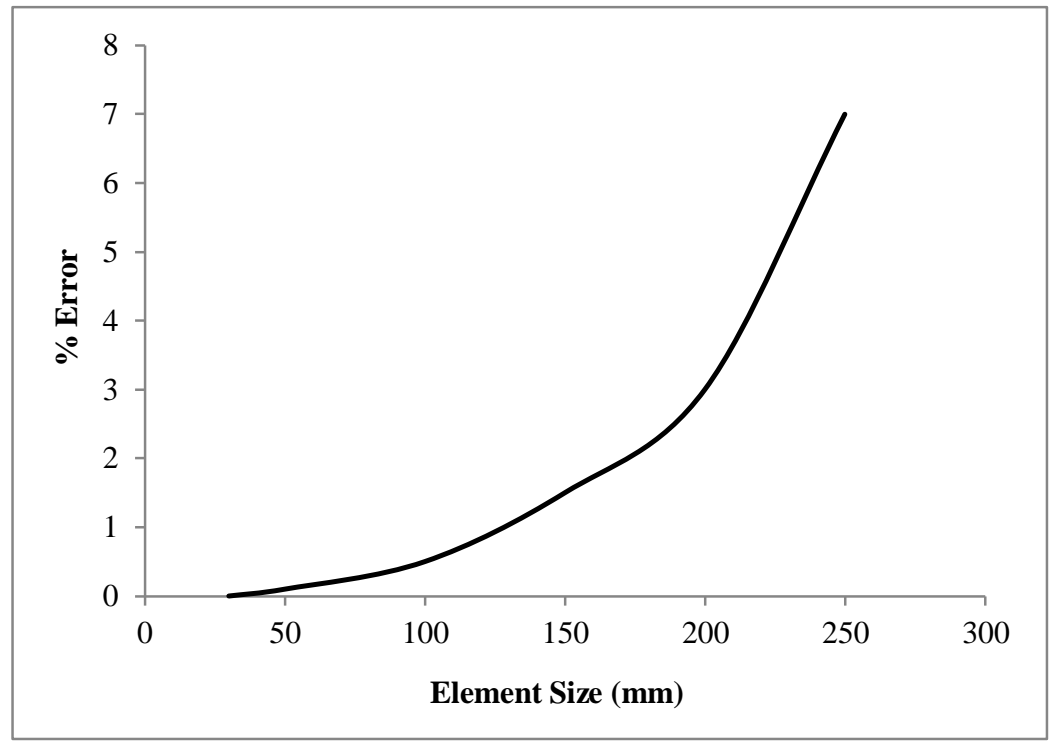

Figure 5. FE mesh size sensitivity 
To validate the modeling procedure, the 3-story SPSW frame tested by In-Rak Choi and Hong-Gun Park [13], was remodeled and analyzed. Based on test results the materials yield stress which were used for infill plate and frame is $299 \mathrm{MPa}$ and $377 \mathrm{MPa}$ respectively. The comparison between experimental and current FE result is shown in Figure 6 . The current FE results show a good agreement with the experiment in both elastic and inelastic stages.

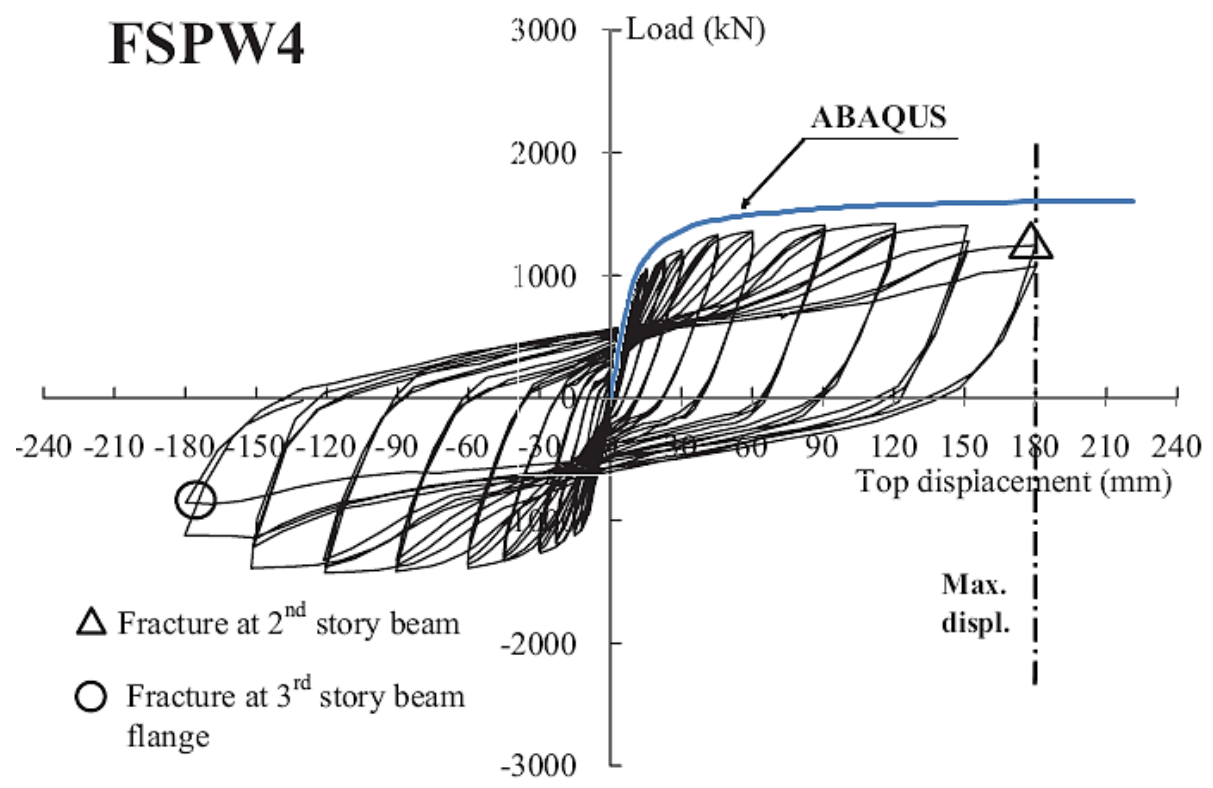

Figure 6. Verification of FE Modeling [13]

The corresponding von Mises stress distribution at the ultimate state is presented in Figure 7. As shown, significant yielding occurred in the infill plate which had less yield stress (300MPa).Also as it is shown plastic hinges formed at ends of HBEs of the 2nd and 3rd story, which comply with the test results reported by In-Rak Choi and Hong-Gun Park [13]
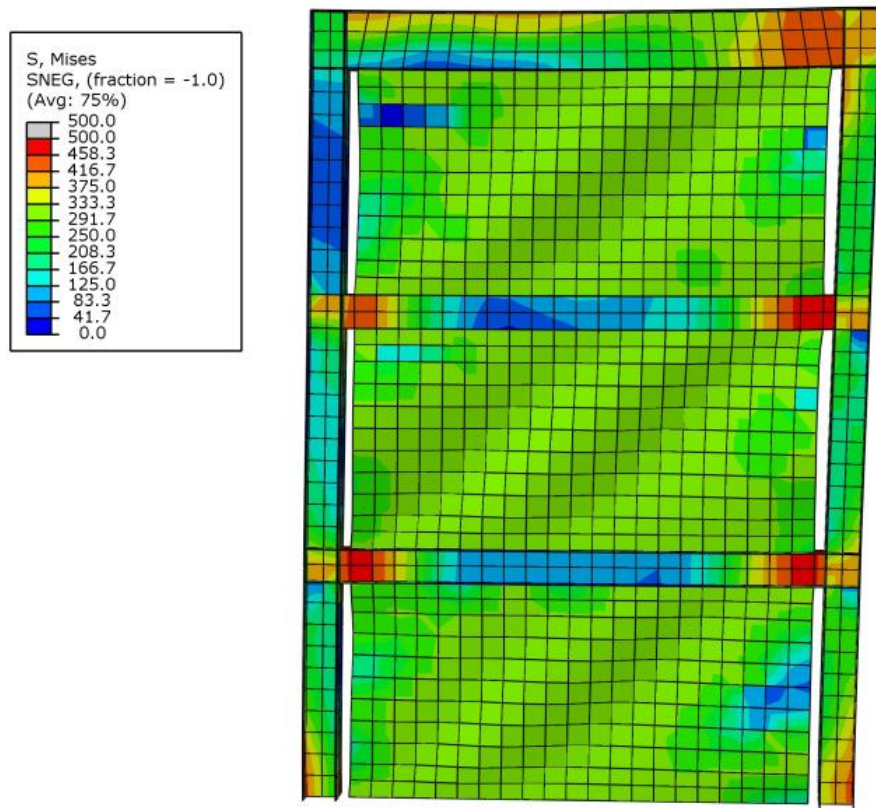

Figure 7. Von Mises Stress Distribution at Ultimate State

\section{Results and Discussion}

The structural characteristics of the models such as initial stiffness, ultimate capacity and axial forces in VBEs are compared and discussed in this section.

\subsection{Load Carrying Capacity}


The push over curves of frames with $3.5 \mathrm{~m}, 7 \mathrm{~m}$ and $8.75 \mathrm{~m}$ are presented in Figures 8 to 10 , respectively. According to results ultimate capacity for models in each group with the same span length is approximately equal which means that designing of the models is well done.

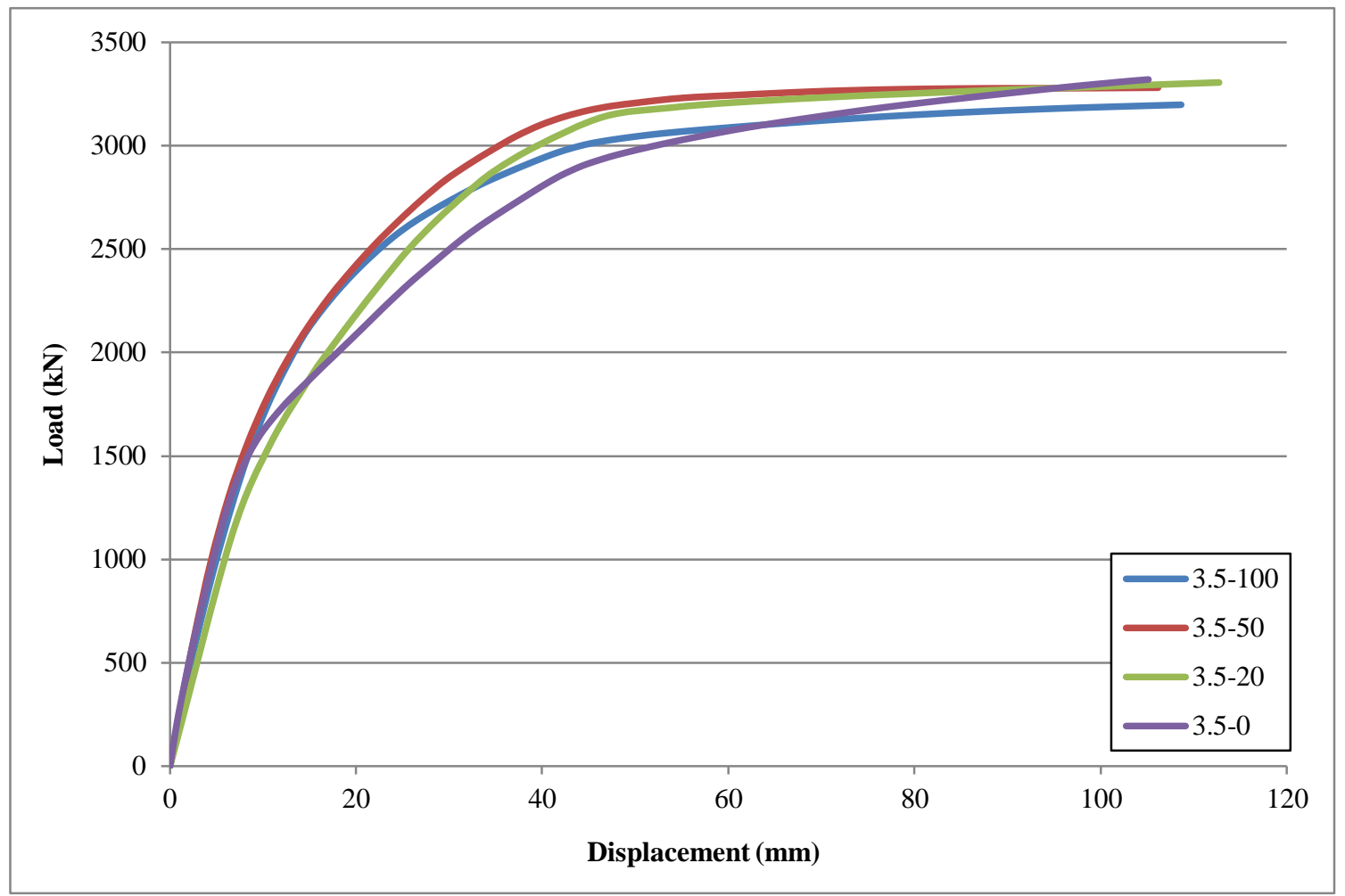

Figure 8. Push Over Curves of 3.5m Span Models

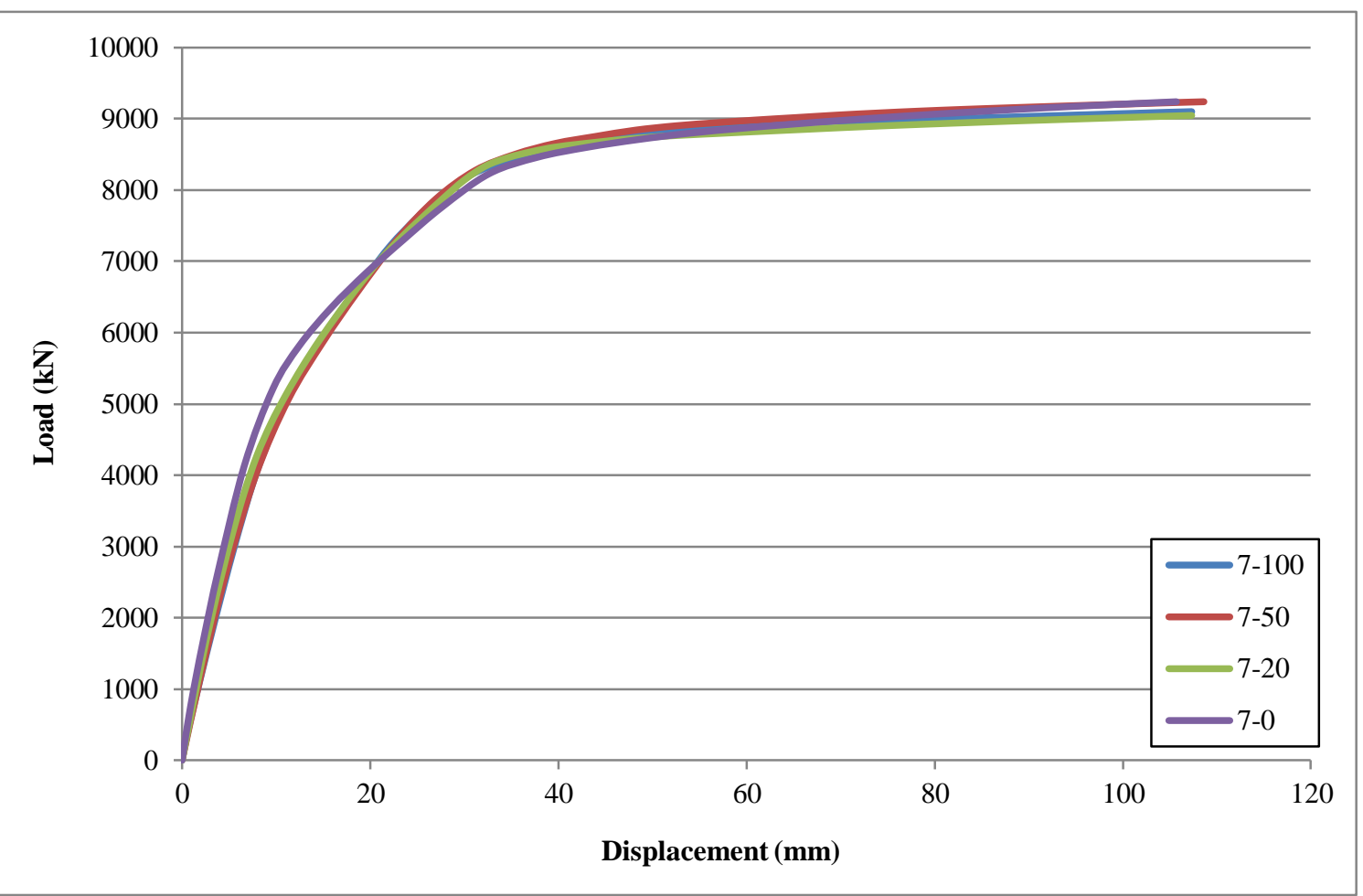

Figure 9. Push Over Curves of 7m Span Models 


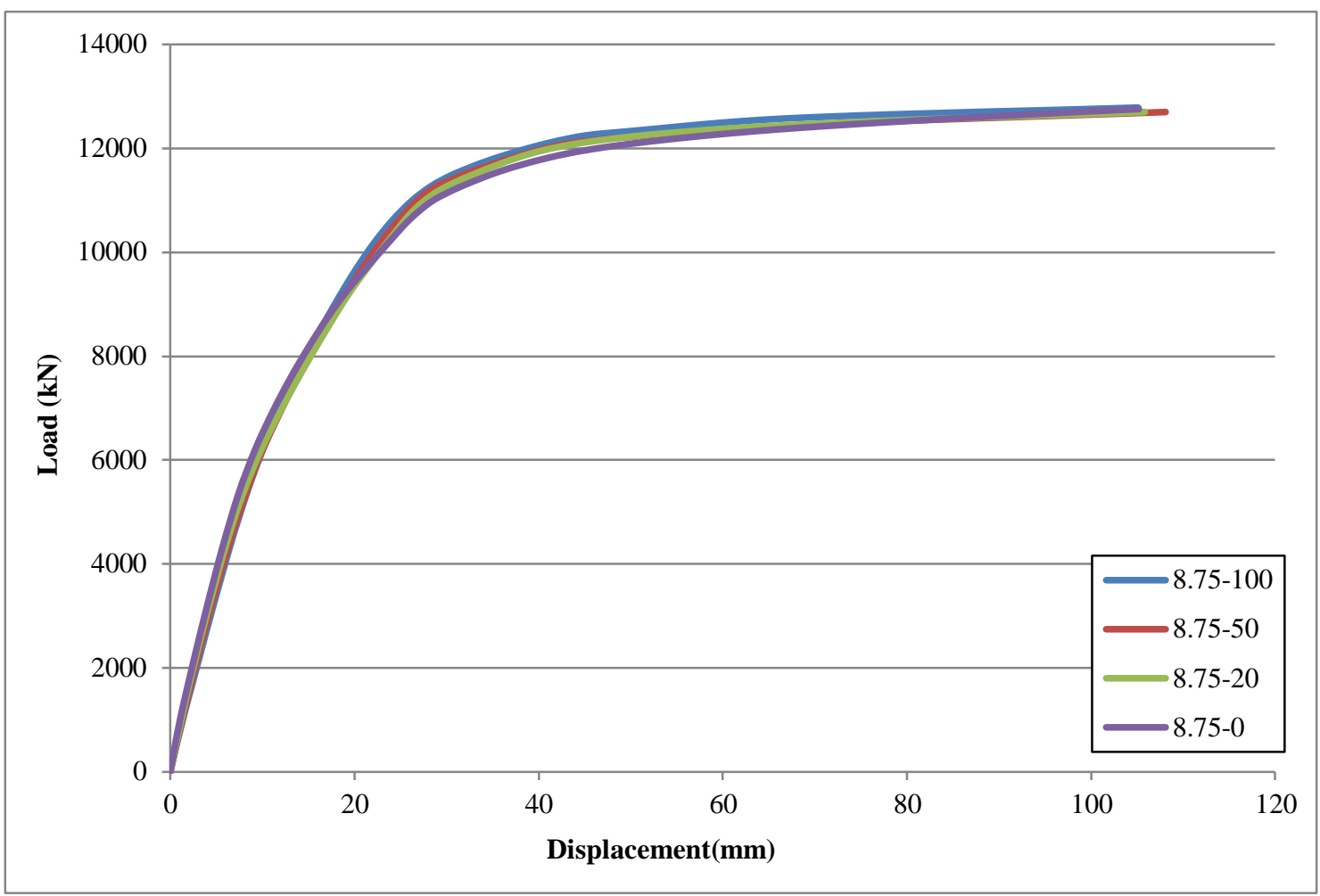

Figure 10. Push Over Curves of 8.75m Span Models

In models with $3.5 \mathrm{~m}$ span length through major differences between infill plate thicknesses, initial stiffness is somewhat different, but in other aspect ratios the initial stiffness is also approximately close. Ultimate capacity and initial stiffness of models are given in Table 4.

Table 4. Ultimate capacity and Initial stiffness of models

\begin{tabular}{|c|c|c|c|c|c|c|c|c|}
\hline \multicolumn{3}{|c|}{ 3.5m span } & \multicolumn{3}{|c|}{$7.5 \mathrm{~m}$ span } & \multicolumn{3}{|c|}{$8.75 \mathrm{~m}$ span } \\
\hline Model & $\begin{array}{c}\text { Ultimate } \\
\text { capacity }(\mathrm{kN})\end{array}$ & $\begin{array}{c}\text { Initial stiffness } \\
(\mathrm{kN} / \mathrm{mm})\end{array}$ & Model & $\begin{array}{c}\text { Ultimate } \\
\text { capacity }(k N)\end{array}$ & $\begin{array}{c}\text { Initial stiffness } \\
(\mathrm{kN} / \mathrm{mm})\end{array}$ & Model & $\begin{array}{c}\text { Ultimate } \\
\text { capacity }(\mathrm{kN})\end{array}$ & $\begin{array}{c}\text { Initial stiffness } \\
(\mathrm{kN} / \mathrm{mm})\end{array}$ \\
\hline $\begin{array}{l}3.5- \\
100\end{array}$ & 3198 & 249 & $7-100$ & 9103 & 591 & $8.75-100$ & 12788 & 741 \\
\hline $3.5-50$ & 3280 & 257 & $7-50$ & 9242 & 598 & $8.75-50$ & 12702 & 756 \\
\hline $3.5-20$ & 3304 & 212 & $7-20$ & 9042 & 662 & $8.75-20$ & 12696 & 823 \\
\hline $3.5-0$ & 3321 & 265 & $7-0$ & 9242 & 712 & $8.75-0$ & 12794 & 886.5 \\
\hline
\end{tabular}

As Table 4 indicates in most cases as connection of infill plate to column is decreases initial stiffness is increased, and the reason of this fact is that increasing the infill plate thickness overcomes decreasing the inclination angle of infill plate through decreasing infill plate to column connection.

\subsection{Axial Forces in VBEs}

The main purpose of using SPSWs in multi span frame and reducing the connection of infill plate is reducing VBE forces. In this section axial forces in VBEs is studied. Figures 11 to 13 illustrate the axial force in compression VBE versus displacement for 3, 7 and $8.75 \mathrm{~m}$ span length models. 


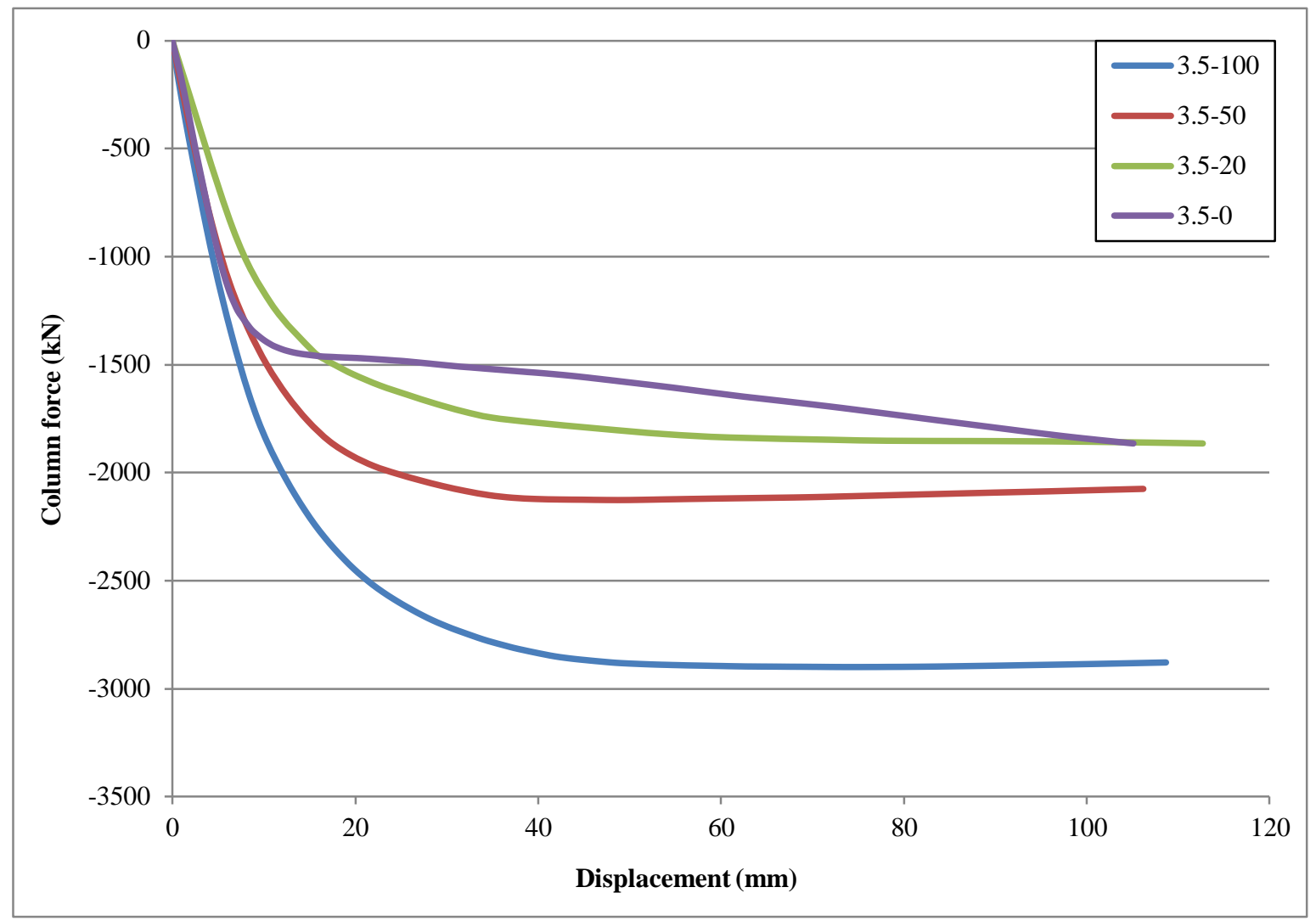

Figure 11. Axial Force in VBEs of $3.5 \mathrm{~m}$ Span Models

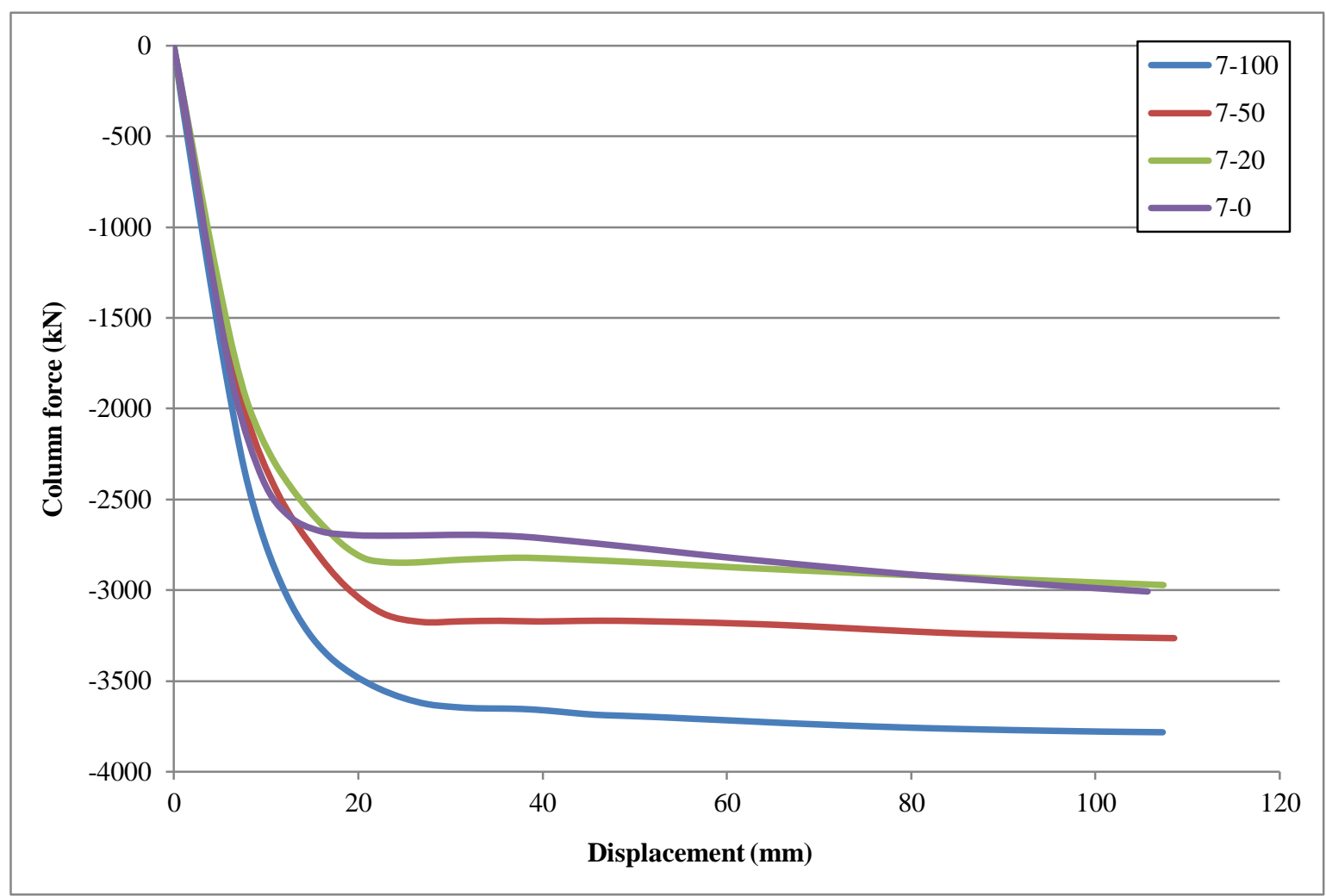

Figure 12. Axial Force in VBEs of $7 \mathrm{~m}$ Span Models 


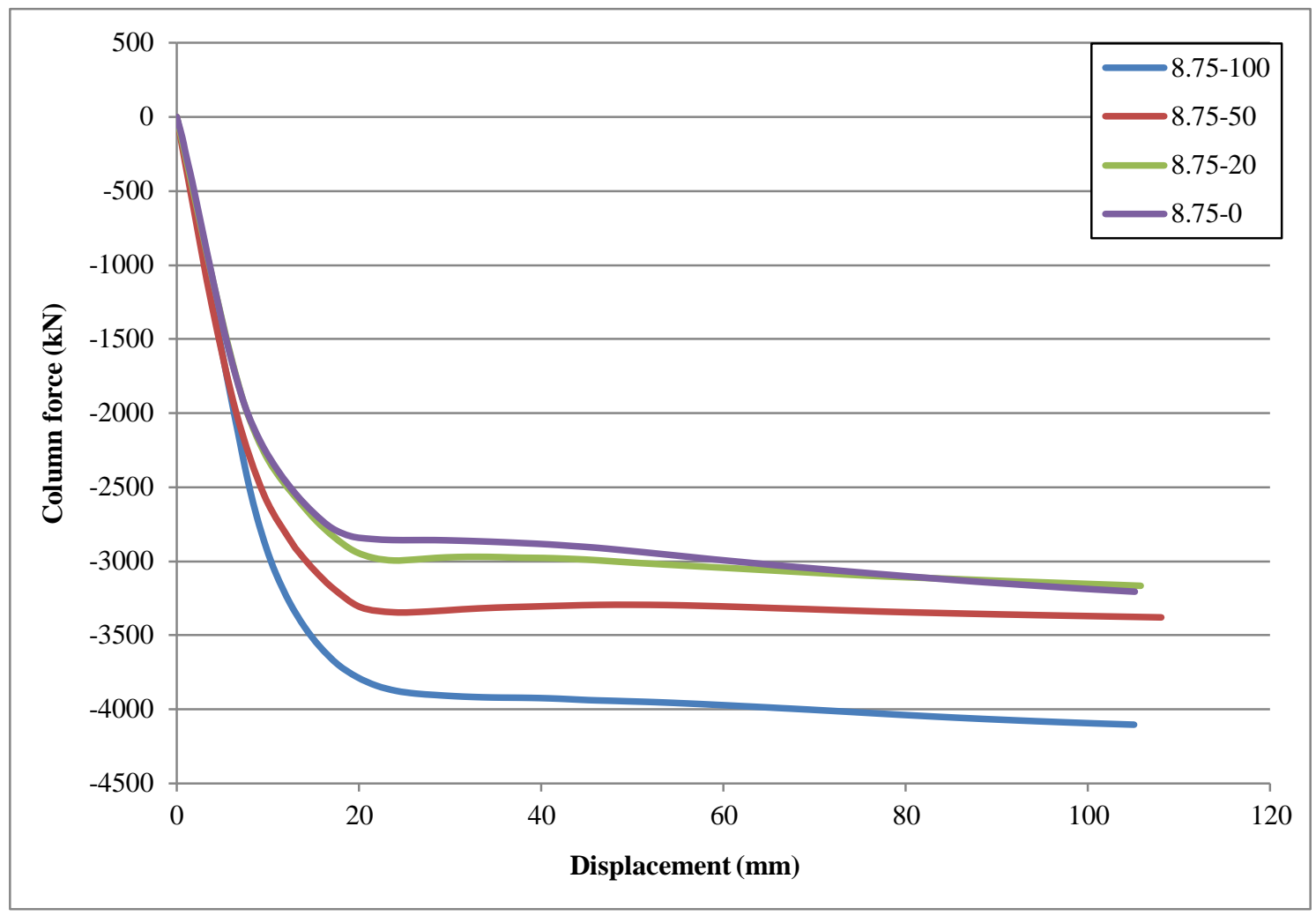

Figure 13. Axial Force in VBEs of $8.75 \mathrm{~m}$ Span Models

As the results show in all span length models the axial force in VBEs reduced as connection of the infill plate to columns reduced. Axial forces of the models at ultimate state is reported in Table 5.

Table 5. Axial force in VBEs

\begin{tabular}{ccc|ccc|ccc}
\hline \multicolumn{3}{c|}{ 3.5m span } & \multicolumn{3}{c|}{$\mathbf{7 . 5}$ m span } & \multicolumn{3}{c}{$\mathbf{8 . 7 5} \mathbf{m}$ span } \\
\hline Model & $\begin{array}{c}\text { Axial force } \\
(\mathbf{k N})\end{array}$ & $\begin{array}{c}\text { Reduction to } \\
\text { base model \% }\end{array}$ & Model & $\begin{array}{c}\text { Axial force } \\
(\mathbf{k N})\end{array}$ & $\begin{array}{c}\text { Reduction to } \\
\text { base model \% }\end{array}$ & Model & $\begin{array}{c}\text { Axial force } \\
(\mathbf{k N})\end{array}$ & $\begin{array}{c}\text { Reduction to } \\
\text { base model \% }\end{array}$ \\
\hline $3.5-100$ & -2900 & - & $7-100$ & -3784 & - & $8.75-100$ & -4144 & - \\
$3.5-50$ & -2125 & 73.3 & $7-50$ & -3262 & 86.2 & $8.75-50$ & -3377 & 81.5 \\
$3.5-20$ & -1863 & 64.2 & $7-20$ & -2970 & 78.5 & $8.75-20$ & -3165 & 76.4 \\
$3.5-0$ & -1863 & 64.2 & $7-0$ & -3007 & 79.5 & $8.75-0$ & -3205 & 77.3 \\
\hline
\end{tabular}

As the results in Table 5 show axial force in models with $20 \%$ connection of infill plate to column and no connection of infill plate and column are close, so it seems that using SPSWs with $20 \%$ connection between infill and column is better than omitting the complete connection because of less steel consumption .

The reason of reduction of axial force in VBEs with reduction of infill plate connection to column is based on the mechanism of load transmission from infill plate to supports. In conventional SPSWs the infill plate vertical load is mainly transmitted through VBEs and outer frames have inconspicuous role in transmitting the infill plate load. But in SPSWs with partially connected infill plate to columns the vertical component of infill plate load mainly transmitted to HBEs and then the outer frames take part to transmit the load to supports.

\subsection{Yielding Distribution}

One of the advantages of SPSWs is energy dissipation through yielding of the infill plate, in this section the pattern of yielding of the infill plate in models is discussed. Figures 14 to 17 illustrate the frame and infill plate stress distribution of $3.5 \mathrm{~m}$ span models. 


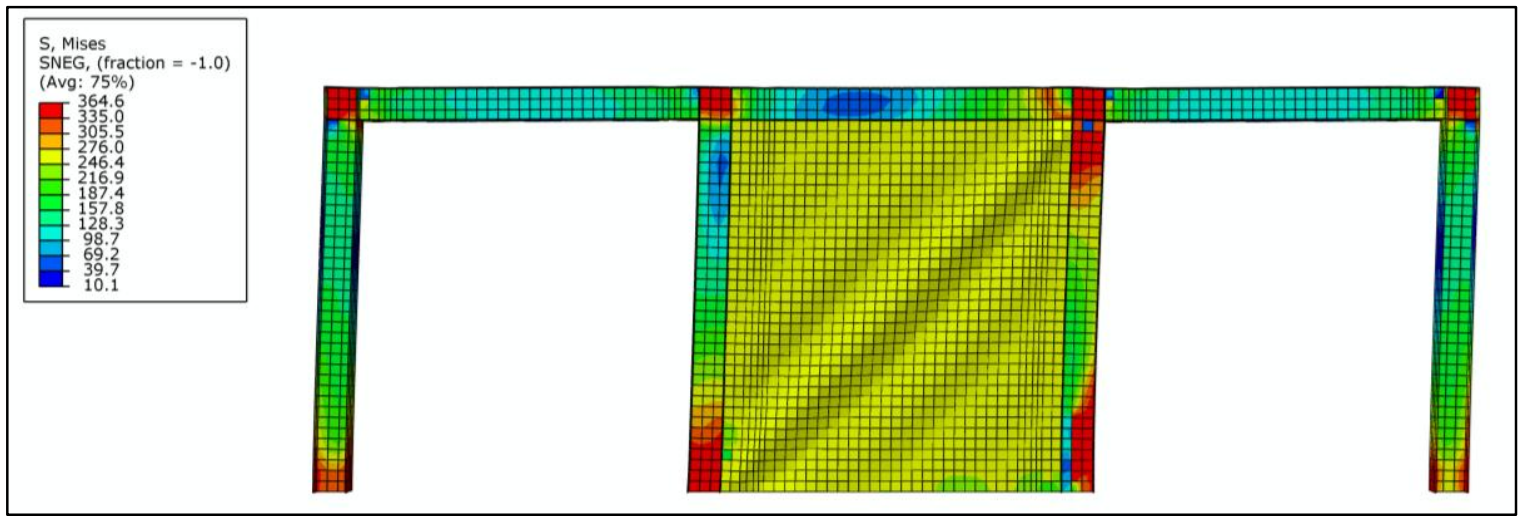

Figure 14. Stress Distribution of Fully Connected 3.5m Span Length Model

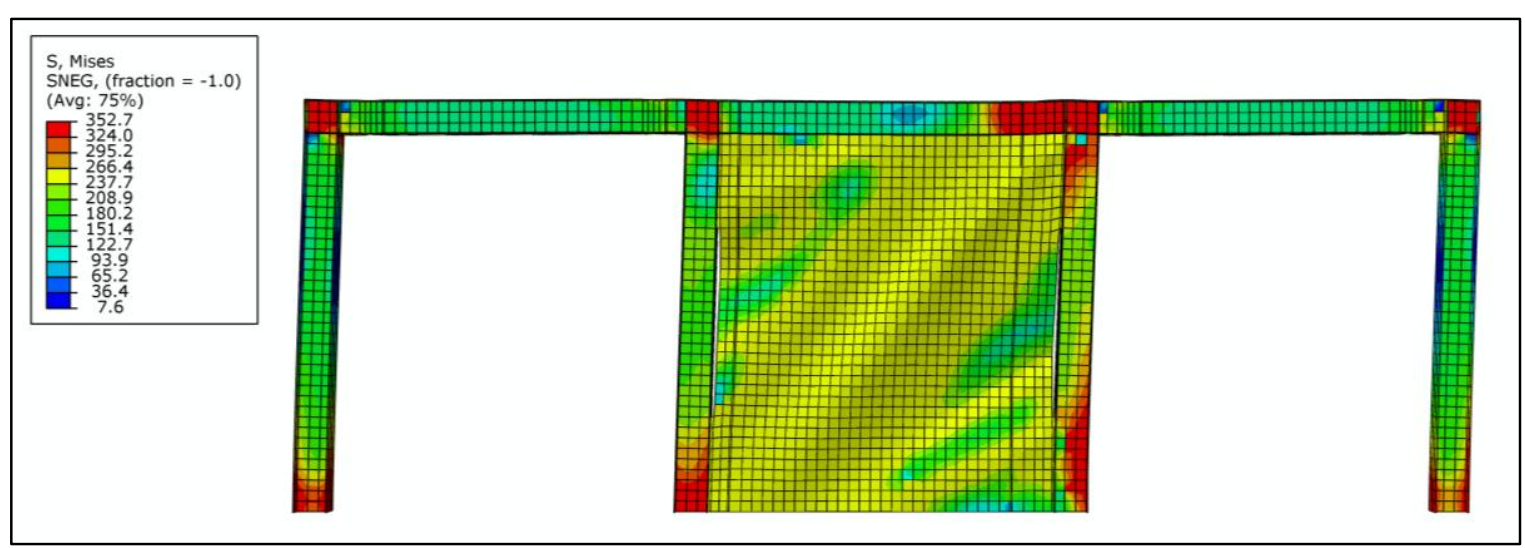

Figure 15. Stress Distribution of 50\% Connected 3.5m Span Length Model

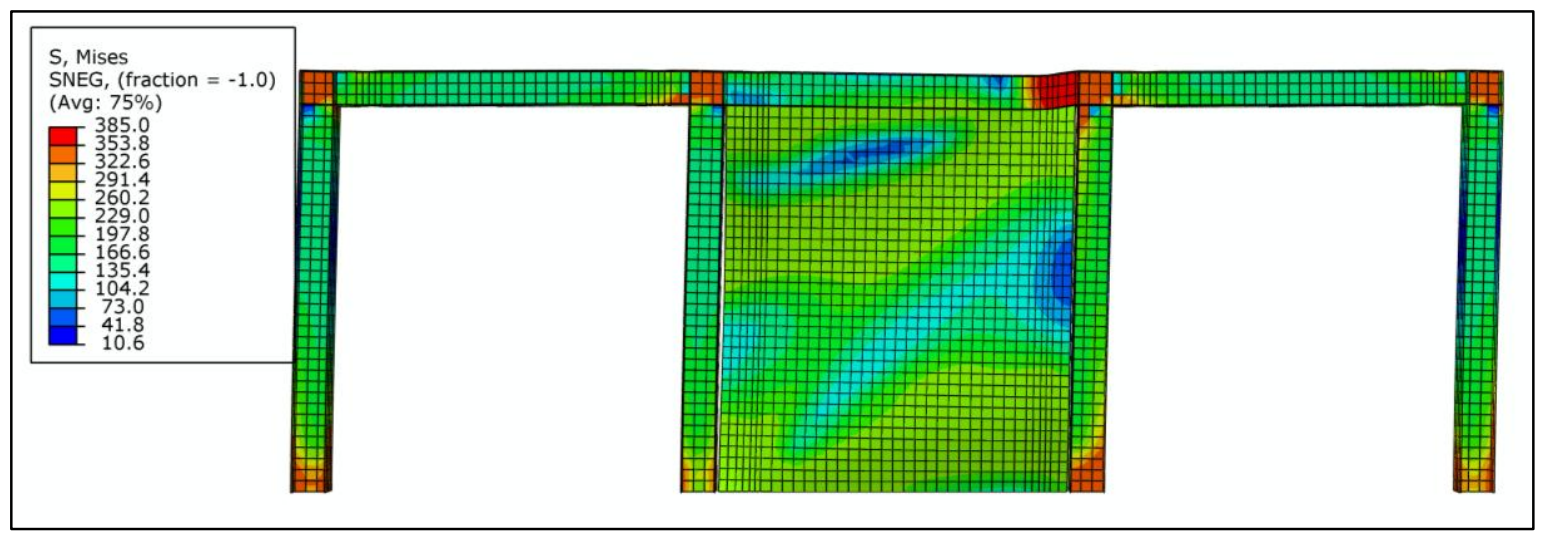

Figure 16. Stress Distribution of 20\% Connected 3.5m Span Length Model

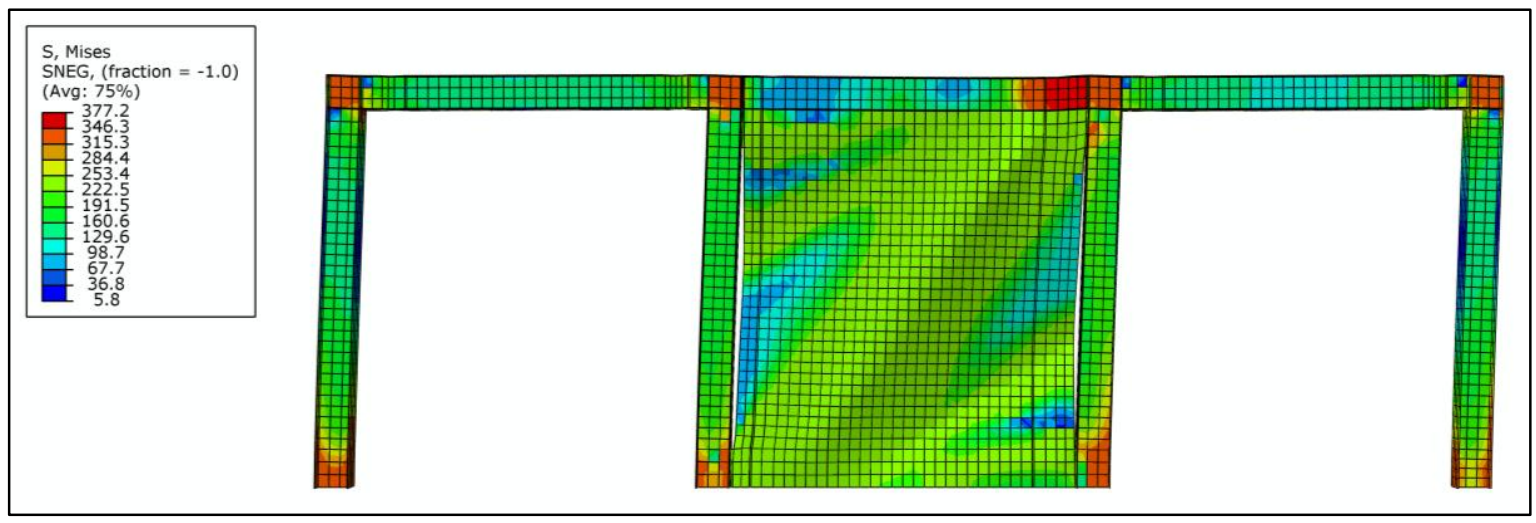

Figure 17. Stress Distribution of NotConnected 3.5m Span Length Model 
As the results shown the connection of infill plate to column effect on infill plate yielding. Reducing the infill plate connection to column causes less yielding in infill plate which was expected based on Figures 2 and 3. Hence reducing the infill plate connection changes the inclination angle of tension field which reduces the plate capacity. Some of this reduction is recovered with using thicker infill plate and the other recovering element is the moment frame action of the outer frames. As moment frame is also a good ductile element reduction in infill plate yielding may not be worrying.

\section{Conclusion}

In this paper push over analysis is performed on 12 multi span one story SPSWs. The frames are designed according to AISC-341 and AISC-360 specifications. The main purpose of this research is the effect of reduction of infill plate connection to columns on columns axial forces. Based on the results obtained in this research the following points are concluded:

- The results show that reducing the connection of infill plate to columns will reduce the SPSW capacity but using thicker plates may recover the capacity.

- Reducing the infill plate connection to column will reduce the axial force in VBEs which is one of most concerns about using SPSWs in buildings. The results show that $20 \%$ connection of infill plate to columns is more efficient than no connection between infill plate and column because with less material consumption the models behave equally.

- As the results show reducing the connection of infill plate to VBEs may lead to lower yielding of infill plate and less nonlinear behavior of infill plate, but using ductile moment frame with excellent seismic behavior along with infill plate will recover this weak point.

\section{References}

[1] Bruneau M, Berman J, Lopez Garcia D, Vian D. "Steel plate shear wall buildings: design requirements and research" , North American steel construction conference, Montreal, Canada, April 2005

[2] Driver RG, Kulak GL, Kennedy DJL, Elwi AE. "Cyclic test of a four storey steel plate shear wall" ASCE Journal of Structural Engineering1998;124 (2):112-20.

[3] Berman JW, BruneauM. "Plastic analysis and design of steel plate shear walls". J Struct Eng ASCE 2003;1 29(11):1448-56.

[4] Zhao Q, Astaneh-As 1A. "Cyclic Behavior of Traditional and Innovative Composite Shear Walls" J Struct Eng ASCE 2004;130(2):271-84.

[5] Qu B, Bruneau M, Lin CH, Tsai KC and Lin YC. "Full scale steel plate shear wall: MCEER/NCREE phase II tests", Ninth Canadian Conference on Earthquake Engineering Ottawa, Ontario,Canada26-29 June2007.

[6] Caccese V, Elgaaly M, Chen R. "Experimental study of thin steel-plate shear walls under cyclic load" .J Struct Eng ASCE1993;119(2):573-87.

[7] Seilie I, Hooper J. "Steel plate shear walls: practical design and construction." Modern Steel Construction 2005(April).

[8] Berman JW. "Seismic behavior of code designed steel plate shear walls" Eng Struct 2011; 33(1): 230-44.

[9] Berman JW, Lowes NL, Okazaki T, Bruneau M, Tsai KC, Driver RG, Sabelli R and Moore WP. "Research Needs and Future Directions for Steel Plate Shear Walls". ASCE Structures Congress, Vancouver, B.C., Canada, 2008.

[10] Via D and Bruneau M. "Steel Plate Shear Walls for Seismic Design and Retrofit of Building Structures", Technical Report MCEER-05-0010, MCEER, Buffalo, NY.

[11] Jahanpour A, Jonsson J and Moharrami H. "Seismic behavior of semi-supported steel shear walls", Journal of constructional steel research,Vol.74, P.118-123, July 2012.

[12] Jahanpour A, Moharrami H and Aghakoochak A. "Evaluation of ultimate capacity of semi-supported steel shear walls", Journal of constructional steel research,Vol.67, P.1022-1030, June 2011.

[13] Choi I.R, and Park H.G. "Steel Plate Shear Walls with Various Infill Plate Designs", Journal of Structural Engineering, Vol. 135, No. 7, July 1, 2009

[14] Vatansever C, Yardimci N. "Experimental investigation of thin steel plate shear walls with different infill-to-boundary frame connections" Steel and Composite Structures, Vol. 11, No. 3 (2011) 251-271

[15] Shekastehband B, Azaraxsh A.A.and Showkati H. "Experimental seismic study on shear walls with fully-connected and beamonly-connected web plates" Journal of constructional steel research, Vol. 141, P.204-215, February 2018. 
[16] Gholipour M, Asadi E and Alinia MM. "The use of outrigger system in steel plate shear wall structures" Journal of Advances in Structural Engineering 18 (6) (2015): 853-872

[17] Safari Gorji M, Roger Cheng J.J. " Steel plate shear walls with outriggers. Part I: Plastic analysis and behavior "Journal of constructional steel research, Vol. 134, P.148-159,July 2017.

[18] Safari Gorji M, Roger Cheng J.J. " Steel plate shear walls with outriggers. Part II: Seismic design and performance "Journal of constructional steel research, Vol. 137, P.311-324,October 2017.

[19] AISC, ANSI/AISC 341-10. "Seismic provisions for structural steel buildings". Chicago (IL): American Institute of Steel Construction. 